\title{
Effect of Picloram, Additives and Plant Growth Regulators on Somatic Embryogenesis of Phyla nodiflora (L.) Greene.
}

\author{
Abdul Bakrudeen Ali Ahmed ${ }^{1,3 *}$, Adhikarla Suryanarayana Rao ${ }^{2}$, Mandali Venkateswara \\ Rao $^{1}$ and Rosna Mat Taha ${ }^{3}$ \\ ${ }^{1}$ Department of Plant Science; School of Life Sciences; Bharathidasan University; 620 024, Tiruchirappalli - India. \\ ${ }^{2}$ Department of Biotechnology; School of Life Sciences; Bharathidasan University; 620 024; Tiruchirappalli - \\ India. ${ }^{3}$ Institute of Biological Sciences; Faculty of Science; University of Malaya; 50603; Kuala Lumpur - Malaysia
}

\begin{abstract}
The present study describes the plant regeneration via somatic embryogenesis in suspension culture derived from the leaf and stem explants of Phyla nodiflora. The medium type, plant growth regulators, complex extract (coconut milk and malt extract) and anti-oxidant (activated charcoal, ascorbic acid, Polyvinylpyrrolidone and citric acid) markedly influenced the embryo regeneration of $\mathrm{P}$. nodiflora. MS with 2,4-D and activated charcoal (10 mg/L) gave the highest stimulation of embryogenic callus growth. Optimized callus was transfered into suspension culture, which showed the globular, heart shaped embryos in MS with 2,4-D + BA + picloram (0.1 mg/L), coconut milk (10 $\mathrm{ml} / \mathrm{L})$, citric acid $(100 \mathrm{mg} / \mathrm{L})$ on $6^{\text {th }}$ subcultures. Further development stages such as torpedo and cotyledonary stage embryos and fostered maturation of embryos were observed at $8^{\text {th }}$ and $10^{\text {th }}$ subculture. However, the high frequency embryo germination and plantlet (45 plants/20 mg cotyledonary stages embryos) formation was obtained in half-strength MS medium without growth regulators from cotyledonary embryos. All the plantlets established in the field exhibited morphological characters similar to those of the mother plant.
\end{abstract}

Key words: Somatic embryogenesis (SEs); picloram; ascorbic acid; coconut milk; plant growth regulators; Murashige and Skoog medium

\section{INTRODUCTION}

Phyla nodiflora L. Greene (= Lippia nodiflora $($ L.) Mihex) belongs to Verbenaceae family, distributed in India, Ceylon, Baluchistan, South Africa and Central America (Terblanche and Kornelin, 1996). It leaves are eaten in Ceylon and taken as tea in the Philippines. It is aromatic, runner plant with scanty roots and cure adenopathy, chronic indolent ulcers, diuretic and aphrodisiac and is also used for the treatment of heart diseases, ulcers, bronchitis, fevers, and colds (Kirtikar and Basu, 1975). The plant is also used for the boils, indigestion in children, and by the women after the delivery (Nadkarni, 1954; Chopra et al., 1956). Ravikanth et al., (2000) reported that the anticancer compounds (halleridone and hallerone) from P. nodiflora.

It also has the alkaloids and shows the significant analgesic, anti-inflammatory and anti-pyretic activities (Costa et al., 1989, Forestieri et al., 1996), anti-cancer, anti-tumor, anti-malarial, antifungal, cytotoxic activity (Nishino et al., 1988), antioxidant and free radical scavenging effect (Ashokkumar et al., 2008), antioxidant

*Author for correspondence: bakru24@yahoo.co.in 
activities (Shukla et al. 2009) and cure multiple skin disease (Abbasi et al., 2010).

The commercial exploitation of the medicinal plants for the production and conventional propagation is hampered due to their poor seed viability, low rate of germination and poor rooting ability of the vegetative cuttings. The alternative propagation methods could be beneficial for accelerating the large scale multiplication and the conservation of the medicinal plant. Since, less in vitro studies have been done in this genus, latest studies on the propagation of Lippia junelliana (Juliani et al., 1999) and Lippia alba (Gupta et al., 2001). Direct shoot propagation using different explants has been implemented (Bhatt et al., 2002; Ahmed et al., 2005). Somatic embryogenesis is an alternative method for the large-scale propagation method. However, for this, there is lack of information for the embryo induction process (Dodeman et al., 1997). The aim of this work was to study the germination capability and development of somatic embryos (SEs) from Phyla nodiflora.

\section{MATERIAL AND METHODS}

\section{Plant material and inoculation}

Phyla nodiflora young plants were collected and maintained in Department of plant science garden, Bharathidasan University, Tiruchirappalli, Tamil Nadu, India. Two years old young leaf and stem explants were washed in running tap water, surface disinfected in a solution of $\mathrm{HgCl}_{2}(0.1 \%$, w/v) containing distilled water for $2 \mathrm{~min}$ and finally rinsed with sterile distilled water for several times. The explants were inoculated into the MS (Murashige and Skoog, 1962); SH (Schenk and Hildebrandt, 1972), WPM (Lloyd and McCown, 1980) and B5 (Gamborg et al., 1968) medium.

\section{Embryogenic callus induction and maturation}

The leaf and stem explants were inoculated into the medium with plant growth regulators and antioxidant. Both the explants were cultured on different media for embryogenic callus induction: namely MS, SH, B5 and WPM supplemented with sucrose $(3 \%, w / v)$, combination with 2,4-D: 0.2 $1.4 \mathrm{mg} / \mathrm{L}, \mathrm{NAA}: 0.2-1.4 \mathrm{mg} / \mathrm{L}$ with ascorbic acid $(10 \mathrm{mg} / \mathrm{L})$ respectively. For SEs maturation, auxins with picloram $(0.01-0.2 \mathrm{mg} / \mathrm{L})$, cytokinins
(BA: 0.1 - $2.0 \mathrm{mg} / \mathrm{L}),(\mathrm{KN}: 0.1-2.0 \mathrm{mg} / \mathrm{L})$, coconut milk (10 ml/L) and citric acid (50 -150 $\mathrm{mg} / \mathrm{L}$ ) were tested in the suspension culture. The media $\mathrm{pH}$ was adjusted to $5.8(1 \mathrm{~N} \mathrm{NaOH} / \mathrm{HCl})$ and after adding the agar $(0.8 \%, \mathrm{w} / \mathrm{v})$ autoclaved at $121{ }^{\circ} \mathrm{C}$ for $15 \mathrm{~min}$. The callus tissue was weighed and placed into $125 \mathrm{ml}$ Erlenmeyer flask containing $60 \mathrm{ml}$ basal medium without agar. Matured cotyledonary embryos were used for plantlets formation in free MS solid medium. All SEs cultures were maintained at $25 \pm 2{ }^{\circ} \mathrm{C}$ under a photoperiod $(16 \mathrm{~h} / 8 \mathrm{~h})$ with light intensity $35 \mu$ $\sum \mathrm{m}^{-2} \mathrm{~s}^{-1}$ and $55-60 \%$ relative humidity. The germinated plantlets were transplanted to plastic pots containing vermiculite supplemented with the nutrient solution (NPK 17:17:17) at weekly intervals.

\section{Statistical analysis}

Only data which showed advantageous effect were included in the tables and presented in mean of explants per treatment and repeated three times. Thirty replicates were used and repeated thrice. Experimental design was completely random and factorial with callus initiation, globular, heart, torpedo and cotyledonary stages of the callus. The data were subjected to analysis of variance and mean seperation was carried out using Duncan's Multiple Range Test (DMRT) at 5\% level significance (Gomez and Gomez, 1976).

\section{RESULTS AND DISCUSSION}

\section{Callus initiation}

In all media, the callus initiation didn't occur without the growth regulators (control) in leaf and stem explants (data not shown). The suitable embryogenic callus induction was observed in 2,4-D and NAA with ascorbic acid in MS, SH, B5 and WPM (Table 1). However in B5, SH and WPM media, the embryogenic potential significantly decreased (data not shown). Callus initiation and proliferation was better in 2,4-D and NAA than IAA, IBA in all media (data not shown). Between the two auxins, 2,4-D $(0.6 \mathrm{mg} / \mathrm{L})$ with ascorbic acid $(10 \mathrm{mg} / \mathrm{L})$ induced higher embyogenic callus in leaf explants $(94.5 \%$; Fig. 1A) than stem explants (76.8\%, Fig. 1 B) after 25 days (Table 1). 
Table 1 - Embryogenic callus induction from leaf and stem explants of Phyla nodiflora on B5, MS, SH, WPM medium supplemented with 2,4-D and NAA, after 25 days.

\begin{tabular}{|c|c|c|c|c|c|c|c|c|c|c|c|c|c|c|c|}
\hline \multirow{3}{*}{\multicolumn{2}{|c|}{$\begin{array}{l}\text { Medium type / } \\
\text { Plant growth } \\
\text { regulators / Explants }\end{array}$}} & \multicolumn{14}{|c|}{ Embryogenic callus frequency $(\%)$} \\
\hline & & \multicolumn{7}{|c|}{ NAA $(\mathrm{mg} / \mathrm{L})+$ Ascorbic acid $(10 \mathrm{mg} / \mathrm{L})$} & \multicolumn{7}{|c|}{ 2,4-D (mg/L) + Ascorbic acid $(10 \mathrm{mg} / \mathrm{L})$} \\
\hline & & s 0.2 & 0.4 & 0.6 & 0.8 & 1.0 & 1.2 & 1.4 & 0.2 & 0.4 & 0.6 & 0.8 & 1.0 & 1.2 & 1.4 \\
\hline B5 & & 32.5 & & & & & $28.5^{\mathrm{d}}$ & & & & 5 & & & $22.6^{\circ}$ & \\
\hline $\mathrm{N}$ & & & & & & $63.0^{\mathrm{a}}$ & $52.4^{\mathrm{a}}$ & 40 & $50.4^{\mathrm{a}}$ & & $94.5^{\mathrm{a}}$ & & & $56.0^{\mathrm{a}}$ & $39.2^{\mathrm{a}}$ \\
\hline & & . & & $54.2^{\mathrm{b}}$ & & $54.1^{\mathrm{b}}$ & $39.5^{\mathrm{b}}$ & 32 & $35.6^{\mathrm{b}}$ & $38.2^{\mathrm{b}}$ & $42.4^{\mathrm{bc}}$ & & & $40.0^{\mathrm{b}}$ & 34.6 \\
\hline & 3 & $39.2^{\mathrm{b}}$ & $40.0^{\mathrm{bc}}$ & $43.5^{\mathrm{c}}$ & $47.3^{\mathrm{cd}}$ & $45.2^{\mathrm{c}}$ & $32.2^{\mathrm{bc}}$ & $26.5^{\mathrm{bc}}$ & $34.2^{\mathrm{bc}}$ & $36.6^{\mathrm{bc}}$ & $45.5^{\mathrm{b}}$ & $51.6^{\mathrm{b}}$ & $48.5^{\mathrm{b}}$ & $35.4^{\mathrm{bc}}$ & $28.0^{\mathrm{c}}$ \\
\hline B5 & & $24.6^{\mathrm{bc}}$ & $29.0^{\mathrm{bc}}$ & $34.5^{b}$ & $40.2^{\mathrm{b}}$ & $36.8^{b}$ & $30.0^{\mathrm{b}}$ & $26.5^{b}$ & $30.6^{\mathrm{b}}$ & $36.2^{\mathrm{b}}$ & $52.2^{\mathrm{b}}$ & $41.8^{\mathrm{b}}$ & $39.6^{\mathrm{ab}}$ & $35.0^{\mathrm{ab}}$ & $26.8^{\mathrm{b}}$ \\
\hline & & $30.5^{\mathrm{a}}$ & & & & $48.0^{\mathrm{a}}$ & $42.6^{\mathrm{a}}$ & $39.0^{\mathrm{a}}$ & $35.8^{\mathrm{a}}$ & $42.5^{\mathrm{a}}$ & $76.8^{\mathrm{a}}$ & & $42.6^{\mathrm{a}}$ & $39.4^{\mathrm{a}}$ & $31.0^{\mathrm{a}}$ \\
\hline & & $26.0^{\mathrm{b}}$ & 29 & $32.2^{\mathrm{bc}}$ & 34. & $33.2^{\mathrm{bc}}$ & $26.8^{\mathrm{bc}}$ & $20.2^{\mathrm{bc}}$ & $21.0^{\mathrm{d}}$ & & $28.2^{\mathrm{cd}}$ & & $26.2^{\mathrm{cd}}$ & $22.8^{\mathrm{cd}}$ & $18.2^{\mathrm{cd}}$ \\
\hline WPM & Stem & $20.6^{\mathrm{d}}$ & $28.4^{\mathrm{d}}$ & $30.2^{\mathrm{d}}$ & $35.8^{\mathrm{c}}$ & $28.5^{\mathrm{d}}$ & $23.6^{\mathrm{d}}$ & $19.2^{\mathrm{d}}$ & $30.0^{\mathrm{bc}}$ & $34.2^{\mathrm{bc}}$ & $36.8^{\mathrm{c}}$ & $38.2^{\mathrm{bc}}$ & $30.2^{\mathrm{c}}$ & $26.8^{\mathrm{c}}$ & $22.2^{\mathrm{c}}$ \\
\hline
\end{tabular}

Values are mean of 30 replicates per treatment and repeated thrice. Values with the same superscript are not significantly different at $5 \%$ probability level according to DMRT.

\section{Somatic embryos maturation in suspension culture}

Embryogenic tissue was maintained and bulked up through secondary somatic embryogenesis. In order to stimulate SE maturation, the pieces of embryogenic tissue (15 to $20 \mathrm{mg}$ ), which considered of immature embryos, were transferred into each conical flask containing suspension maturation medium supplemented with picloram and additives. The suspension culture was superior in embryogenic callus maturation than semisolid culture of leaf explants. In order to determine the effect of PGRs on somatic embryogenesis in $P$. nodiflora, the highest frequency embryos at the globular stage $(89.8 \%)$, heart stage $(74.9 \%)$ were observed onto media suplemented with 2,4-D (0.6 $\mathrm{mg} / \mathrm{L})+\mathrm{BA}(1.0 \mathrm{mg} / \mathrm{L})+$ picloram $(0.1 \mathrm{mg} / \mathrm{L})+$ coconut milk $(10 \mathrm{ml} / \mathrm{L})$ with citric acid $(100 \mathrm{mg} / \mathrm{L})$ in 40 and 60 days. During the embryos maturation, the suspension culture was continuously subculture every week to prevent the re-callus and phenolic excretion in the medium.

\section{Torpedo and cotyledonary stages in suspension culture}

The advantage of suspension culture was that the large number of free single cells were aggregated and it could be easily identified from the undifferentiated and differentiated cells (developmental stages) of SEs (Fig. 1C-I). However, the abnormal embryos were trumpetshaped and didn't show any further development. Torpedo and cotyledonary stages embryos development were observed in MS medium with
2,4-D $(0.6 \mathrm{mg} / \mathrm{L})+\mathrm{BA}(1.0 \mathrm{mg} / \mathrm{L})+$ picloram $(0.1$ $\mathrm{mg} / \mathrm{L})+$ coconut milk $(10 \mathrm{ml} / \mathrm{L})$, citric acid $(100$ $\mathrm{mg} / \mathrm{L})$ to form torpedo $(62.6 \%)$ and cotyledonary stage embryos $(55.2 \%)$ in suspension culture (Table 2).

\section{Germination and field survival}

The mature cotyledonary embryos were transferred to half-strength MS medium without growth regulators which showed the increase frequency of plantlets than full strength medium (Fig. 2). In germination experiment, a total of 100 mature embryos $(20 \mathrm{mg}$ ) were selected on placed on the germination media. These embryos were responded differently on half-strength and full strength germination media. $52 \%$ of these embryos were showed root emergence in half strength MS medium, which included root and shoot in 140 days. While $26 \%$ (100 days) and $40 \%$ (120 days) of them demonstrated the shoot and root initiation. About 160 days (44\%) of all developed embryos were significantly reduced the germination nature without hardened. Significantly reduced abnormal embryos were observed in fullstrength MS medium (data not shown). The SEs germination in the present study could be due to the persistence of auxins, which might also be the cause of dedifferentiation of embryos. However, in half-strength medium the plantlets were recovered (45 plantlets / $20 \mathrm{mg}$ cotyledonary embryo callus) in 120 days. The germinated plantlets were individually transferred to the pots containing soil, sand and farmyard manure (1:1:1) and were reared in the green house (Fig. 1K). 

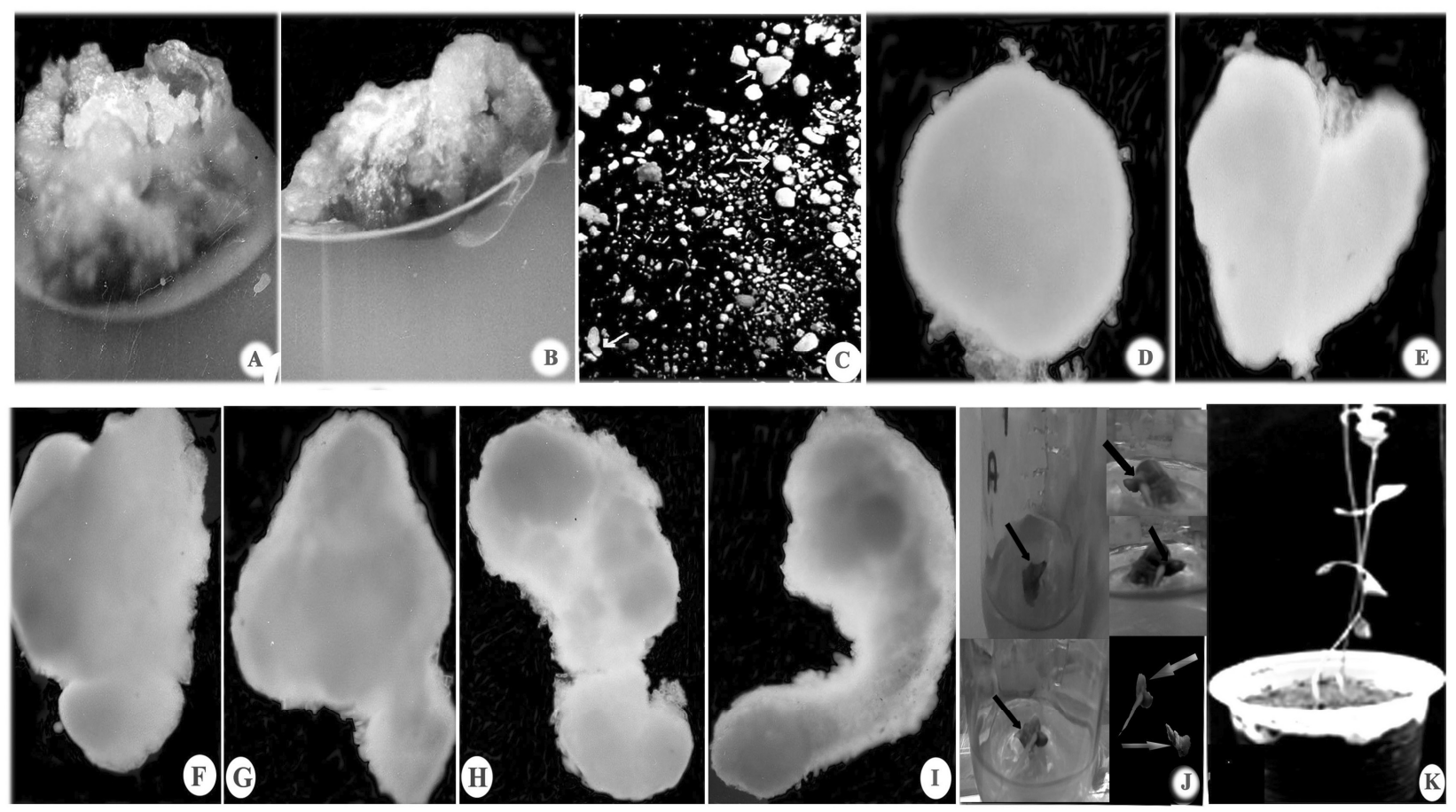

Figure 1 - Plant regeneration from leaf and stem explants of Phyla nodiflora (L.) Greene via somatic embryogenesis

A - Embryogenic callus (leaf explant); B - Embryogenic callus (Stem explant); C Different stages embryos (leaf explants); D - Globular shaped embryo; E - Heart shaped embryo; F and $\mathrm{G}$ - Torpedo stage embryo; H - Late torpedo stage embryo; I - Early cotyledonary stage embryo; $\mathrm{J}$ - Embryo germination; $\mathrm{K}$ - Germinated plantlets maintained in the field.

Table 2 - Somatic embryogenesis from callus induced from leaf and stem explants of Phyla nodiflora on MS medium supplemented with 2,4-D, picloram and BA in suspension culture at different days

\begin{tabular}{|c|c|c|c|c|c|c|}
\hline \multicolumn{3}{|c|}{ Plant growth regulators (mg/L) } & $\begin{array}{l}\text { Globular }(\%) \\
4^{\text {th }} \text { subculture }\end{array}$ & $\begin{array}{c}\text { Heart }(\%) \\
6^{\text {th }} \text { subculture }\end{array}$ & $\begin{array}{l}\text { Torpedo }(\%) \\
8^{\text {th }} \text { subculture }\end{array}$ & $\begin{array}{c}\text { Cotyledonary (\%) } \\
10^{\text {th }} \text { subculture }\end{array}$ \\
\hline \multicolumn{2}{|c|}{$\begin{array}{l}\text { Coconut milk } \\
(10 \mathrm{ml} / \mathrm{L})\end{array}$} & $\begin{array}{l}\text { + Citric acid } \\
(100 \mathrm{mg} / \mathrm{L})\end{array}$ & 40 days & 60 days & 80 days & 90 days \\
\hline $2,4-\mathrm{D}$ & Picloram & BA & & & & \\
\hline 0.6 & 0.01 & 0.5 & $72.6 \pm 1.7^{\mathrm{c}}$ & $61.3 \pm 1.5^{\mathrm{bc}}$ & $49.5 \pm 1.0^{\mathrm{c}}$ & $36.2 \pm 1.4^{\mathrm{bc}}$ \\
\hline 0.6 & 0.1 & 0.5 & $65.2 \pm 1.3^{\text {ef }}$ & $56.4 \pm 2.1^{\mathrm{de}}$ & $38.8 \pm 1.5^{\mathrm{ef}}$ & $29.6 \pm 2.0^{f}$ \\
\hline 0.6 & 0.2 & 0.5 & $59.1 \pm 0.9^{g}$ & $52.8 \pm 2.5^{\mathrm{f}}$ & $32.6 \pm 3.2^{\mathrm{h}}$ & $25.8 \pm 1.0^{\mathrm{h}}$ \\
\hline 0.6 & 0.01 & 1.0 & $78.5 \pm 2.1^{b}$ & $59.6 \pm 1.8^{\mathrm{d}}$ & $46.1 \pm 2.1^{\mathrm{cd}}$ & $38.4 \pm 1.7^{\mathrm{b}}$ \\
\hline 0.6 & 0.1 & 1.0 & $89.8 \pm 2.8^{\mathrm{a}}$ & $74.9 \pm 0.6^{\mathrm{a}}$ & $62.6 \pm 1.8^{\mathrm{a}}$ & $55.2 \pm 2.2^{\mathrm{a}}$ \\
\hline 0.6 & 0.2 & 1.0 & $71.4 \pm 1.5^{\mathrm{cd}}$ & $64.6 \pm 2.2^{\mathrm{b}}$ & $56.4 \pm 1.3^{\mathrm{b}}$ & $32.5 \pm 1.9^{\mathrm{d}}$ \\
\hline 0.6 & 0.01 & 1.5 & $69.7 \pm 1.4^{\mathrm{e}}$ & $52.3 \pm 1.3^{\mathrm{fg}}$ & $41.2 \pm 1.4^{\mathrm{e}}$ & $31.0 \pm 0.9^{\mathrm{de}}$ \\
\hline 0.6 & 0.1 & 1.5 & $53.2 \pm 1.7^{\mathrm{h}}$ & $47.6 \pm 1.9^{\mathrm{h}}$ & $37.9 \pm 1.6^{\mathrm{g}}$ & $27.8 \pm 1.3^{\mathrm{fg}}$ \\
\hline 0.6 & 0.2 & 1.5 & $46.0 \pm 2.1^{\mathrm{i}}$ & $34.1 \pm 2.0^{\mathrm{i}}$ & $29.5 \pm 2.1^{\mathrm{hi}}$ & $18.2 \pm 2.2^{\mathrm{i}}$ \\
\hline
\end{tabular}

Values are mean of 30 replicates per treatment and repeated thrice. Values with the same superscript are not significantly different at $5 \%$ probability level according to DMRT. 

No of explants/ 20 mg Cotyledonry callus

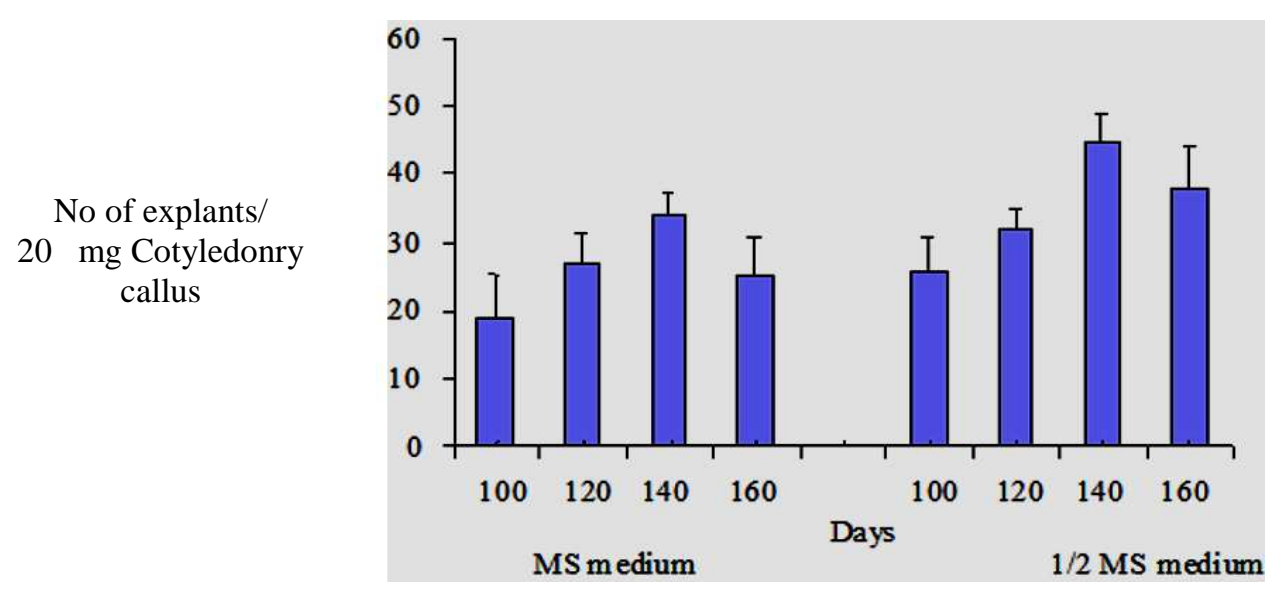

Figure 2 - Somatic embryos germination from cotyledonry stage embryos of Phyla nodiflora in different days.

\section{DISCUSSION}

\section{Influence of medium and plant growth regulators}

When the leaf and stem explants were immersed into B5, SH, WPM media with plant growth regulators and ascorbic acid, the somatic embryos callus initiation was significantly reduced, even if they were maintained for longer period in the culture. Zimmerman, (1993) reported that the proembryogenic callus were containing auxins to synthesize all the necessary genes to complete the globular stage. However, the auxins were removed from the culture to make inactive genes or synthesize new gene products for the completion of embryo development. Kawahara and Komamine (1995) reported that the exogenous auxins were involved in gene expression of early stages of somatic embryogenesis. However, Wang et al. (2006) reported that the NAA $(0.2 \mathrm{mg} / \mathrm{L})$ and 2,4-D $(0.2 \mathrm{mg} / \mathrm{L})$ induced the embryogenic callus in Chorispora bungeana; similar results were observed in Phoenix dactylifera (Fki et al., 2003, Lin et al., 2004). In other plant species, the 2,4-D influenced the embryo induction and participation at initial stages of development (Gray et al., 1993; Mujib and Samaj, 2006; Junaid et al., 2007; Sharma et al., 2007). In the present study work in $P$. nodiflora NAA was less effective compared to 2,4-D.
Influence of additives and coconut milk in somatic embryos maturation

Successful somatic embryogenesis was after obtained in the optimum concentration of auxins combined with cytokinins, picloram, additives (citric acid) and coconut milk. The activated charcoal, polyvinylpyrrolidone and malt extracts, however significantly reduced the somatic embryos quality (data not shown). Guo and Zhang (2005) reported more frequency of SEs maturation in MS medium supplemented with 2,4-D (0.2 $\mathrm{mg} / \mathrm{L})+\mathrm{BA}(5.0 \mathrm{mg} / \mathrm{L})$ in Zingiber officinale. Hence, tests were conducted without picloram and additives in addition to plant growth regulators, which showed that the SEs maturation was significantly reduced (data not shown). Firoozabady and Moy (2004) reported picloram as one of embryogenic potentials agent to increase the growth regulators in Ananas comosus. However, picloram regulated the embryogenic stages and produced maximum frequency of SEs and plant germination (Little et al., 2000; Groll et al., 2001). Somatic embryos maturation was stimulated by auxins combine with cytokinins in Leptadenia reticulata (Martin, 2004).

\section{Influence of strength media in plant germination}

The suspension culture derived from the cotyledonary embryos were transferred to full and 
half strength medium with auxins. Somatic embryos were exposed to too much auxin during the development, but failed to accumulate the storage protein and germinate at a lower frequency (Stuart et al., 1984). The present results showed that somatic embryos germinated without auxins. However, SEs maturation and germination were critical steps for the recovery of healthy plants (Ramanjini and Prakash, 1998). Hwang (2006) reported that $87 \%$ SEs successfully developed into plantlets on $1 / 2$ MS medium without growth regulators after six weeks culture in Abelmoschus manihot.

In conclusion, somatic embryos were induced from the immature zygotic embryos by picloram in suspension culture. The best embryo callus induction in MS medium with $0.1 \mathrm{mg} / \mathrm{L}$ picloram in the leaf explants were optimum for torpedo and cotyledonary stage embryos. The somatic embryo development total process was completed in 160 days. This efficient somatic embryos protocol could be useful for conservation and agronomy and in the improvement of $P$. nodiflora using gene transfer biotechnologies.

\section{REFERENCES}

Abbasi, A.M., Khan, M.A., Ahmed, M., Zafar, M., Jahan, S., Sultana, S (2010), Ethnopharmacological application of medicinal plants to cure skin diseases and in folk cosmetics among the tribal communities of North-West Frontier Province, Pakistan. $J$. Ethnopharmacol., 128, 322-335.

Ahmed, A.B.A., Gouthaman, T., Rao, A.S., Rao, M.V. (2005), Micropropagation of Phyla nodiflora (L.) Greene: An important medicinal plant. Iranian $J$. Biotech. 3, 186-190.

Ashokkumar, D., Thamilselvan, V., Senthilkumar, G.P., Mazumder, U.K., Gupta, M. (2008), Antioxidant and free radical scavenging effects of lippia nodiflora. Phamaceutical Biol., 46, 762-771.

Bhatt, T., Jain, V., Jayathiratha, M.G., Banerjee, G., Mishra, S.H. (2002), In vitro regeneration of roots of Phyla nodiflora and Leptadenia reticulate and comparison of roots from cultured and natural plants for secondary metabolites. J. Exp. Biol., 40, 13821386.

Chopra, R.N., Nayer, S.L., Chopra, I.C. (1956), Glossary of Indian Medicinal Plants, CSIR, V edition, New Delhi, 12, p. 157.
Costa, M., Di Stasi, L.C., Kirizawa, M., Mendacolli, S.L., Gomes, C., Trolin, G. (1989), Screening in mice of some medicinal plants used for analgesic purposes in the state of Sao Pauco. Part II. J. Ethnopharmacol. 27, 25-39.

Dodeman, V.L., Ducreux, G., Kresis, M. (1997), Zygotic embryogenesis versus somatic embryogenesis. J. Exp Bot., 48, 1493-1509.

Firoozabady, E., Moy, Y. (2004), Regeneration of pineapple plants via somatic embryogenesis and organogenesis. In Vitro Cell. Dev. Biol., 40, 67-74.

Fki, L., Masmoudi, R., Drira, N., Rival, A. (2003), An optimized protocol for plant regeneration from embryogenic suspension cultures of date palm, Phoenix dactylifera L., cv. Deglet Nour. Plant Cell Rep., 21, 517-524.

Forestieri, A.M., Monforte, M.T., Ragusa, S., Trovato, A., Lauk, L. (1996), Anti-inflammatory, analgesic and pyretic activity in rodents of plant extracts used in Africa medicine. Phytothera. Resear., 10, 100-106.

Gambrog, O.L., Miller, R.A., Ojima, K. (1968), Nutrients requirements of suspension culture of soybean root cells. Exp. Cell. Res., 50, 151-158.

Gomez, K.A., Gomez, A.A. (1976), Statistical procedures for agricultural research with emphasis on rice. International Rice Research Institute. Los Banos, Philippines, p. 264.

Gray, D.J., McColley, D.W., Compton, M.E. (1993), High frequency embryogenesis from quiescent seed cotyledons of Cucumis melo cultivars. J. Amer. Soc. Hort. Sci., 118, 425-432.

Groll, J., Mycock, D.J., Gray, V.M., Lamenski, S. (2001), Secondary somatic embryogenesis of Cassava on picloram supplemented media. Plant Cell Tiss. Org. Cult., 65, 201-210.

Guo, Y., Zhang, Z. (2005), Establishment of plant regeneration of somatic embryogenic cell suspension cultures of the Zingiber officinale Rosc. Scientia Hort., 107, 90-96.

Gupta, S.K., Khanuja, S.P.S., Kumar, S. (2001). In vitro propagation of Lippia alba. Current Sci., 81, 206210.

Hwang, S.J. (2006), Somatic embryogenesis and plant regeneration in Abelmoschus manihot (L.) medicus. Prop. Orn. Plants., 6, 34-38.

Juliani, H.R., Koroch, A.R., Juliani, H.R., Trippi, V.S. (1999), Micropropagation of Lippia junelliana (Mold.) Tronc. Plant Cell Tiss. Org. Cult., 59, 175179.

Junaid, A., Mujib, A., Bhat, M.A., Sharma, M.P., Samaj, J. (2007), Somatic embryogenesis and plant regeneration in Catharanthus roseus. Biologia plant., 51, 641-646. 
Kawahara, R., Komamine, A. (1995), Molecular basis of somatic embryogenesis. In: Biotechnology in Agriculture and Forestry, Somatic Embryogenesis and Synthetic Seed, Vol. 30. In: Bajaj, Y. P. S. ed. Springer-Verlag, Berlin, Heidelberg, New York, pp. 30-40.

Kirtikar, K.R., Basu, B.D. (1975), In: Indian medicinal plants, 2nd ed. Jayeed press, New Delhi, Vol-III, 1916 - 1917.

Lin, C.S., Lin, C.C., Chang, W.C. (2004), Effect of thidiazuron on vegetative tissue-derived somatic embryogenesis and flowering of bamboo Bambusa edulis. Plant Cell Tiss. Org. Cult. 76, 75-82.

Little, E.L., Magbana, Z.V., Parrott, W.A. (2000), A protocol for repetitive somatic embryogenesis from mature peanut epicotyl. Plant Cell Rep., 19, 351-357.

Lloyd, G., McCown, B. (1980), Commercially feasible micropropagation of mountain laurel, Kalmia latifolia, by use of shoot tip culture. Intl. Plant Prop. Soc. Proc., 30, 421-427.

Martin, K.P. (2004), Benzyl adenine induced somatic embryogenesis and plant regeneration of Leptadenia reticulate. Biol. Plant., 48, 285-288.

Mujib, A., Samaj, J. (ed.) (2006), Somatic embryogenesis. Springer Verlag, Berlin-HeidelbergNew York.

Murashige, T., Skoog, F.A. (1962), Revised media for rapid growth and bioassay with tobacco tissue cultures. Physiol. Plant., 15, 473-497.

Nadkarni, A.K. (1954), Indian Materia Medica, Bombay: Popular Book Depot, p. 280-281.

Nishino, C., Kobayashi, K., Fukushima, M. (1988), Halleridone, a cytotoxic constitutent from Cornus controversa. J. Nat Prod., 51, 1281-1282.
Ramanjini, G.P.H., Prakash, C.S. (1998), Herbicide glyphosate at sublethal concentrations enhances somatic embryo development in sweet potato (Ipomea batatus L.). Current Sci., 75, 508-510.

Ravikanth, V., Ramesh, P., Diwan, P.V., Venkateswarlu, Y. (2000), Halleridone and Hallerone from Phyla nodiflora (L.) Greene. Biochemical Systematic Ecology, 28, 905-906.

Schenk, R.V., Hildebrandt, A.C. (1972), Medium and techniques for induction of growth of monocotyledonous and dicotyledonous plant cell cultures. Can J. Bot., 50, 166-204.

Sharma, S.K., Bryan, G.J., Millam, S. (2007), Auxin pulse treatment holds the potential to enhance efficiency and practicability of somatic embryogenesis in potato. Plant Cell Rep., 26, 945950.

Shukla, S., Saluja, A.K., Pandya, S.S. (2009), In vitro antioxidant activity of aerial parts of Lippia nodiflora Rich. Pharmacology Online, 2, 450-459.

Stuart, D.A., Strickland, S.G. (1984), Somatic embryogenesis from cell cultures of Medicago sativa L. I. Effect of amino acid additions to the regeneration medium. Plant Sci. Lett., 34, 165-174.

Terblanche, F.C., Kornelius, G. (1996), Essential oil constituents of the genus lippia (Verbinaceae) - A literature review. Journal of Essential Oil Research, 8, 471-485.

Wang J, An L, Wang R, Yang D, Si J, Fu X, Chang J, $\mathrm{Xu} \mathrm{S} \mathrm{(2006),} \mathrm{Plant} \mathrm{regeneration} \mathrm{of} \mathrm{Chorispora}$ bungeana via somatic embryogenesis. In Vitro Cell. Develop. Biol.-Plant., 42, 148-151. 